\title{
A More Optimistic Perspective on Government-Supported Marriage and Relationship Education Programs for Lower Income Couples
}

\author{
Alan J. Hawkins \\ Brigham Young University - Provo, hawkinsa@byu.edu \\ Scott M. Stanley \\ University of Denver \\ Philip A. Cowan \\ University of California, Berkeley

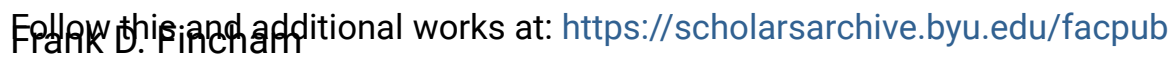

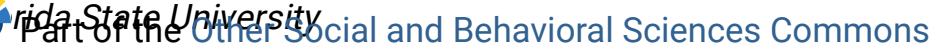

Steven R. H. Beach

\section{Originsablybublication Citation}

Hawkins, A. J. Stanley, S. M., Cowan, P. A., Fincham, F. D., Beach, S. R. H., Cowan, C. P., Rhoades, G. K., Markman, H. J. \& Daire, A. P. (2013). A more optimistic perspective on governmentsupported marriage and relationship education programs for lower income couples. American Psychologist, 68, 110-111.

\section{BYU ScholarsArchive Citation}

Hawkins, Alan J.; Stanley, Scott M.; Cowan, Philip A.; Fincham, Frank D.; Beach, Steven R. H.; Cowan, Carolyn Pape; Rhoades, Galena Kline; Markman, Howard J.; and Daire, Andrew P., "A More Optimistic Perspective on Government-Supported Marriage and Relationship Education Programs for Lower Income Couples" (2013). Faculty Publications. 4240.

https://scholarsarchive.byu.edu/facpub/4240

This Peer-Reviewed Article is brought to you for free and open access by BYU ScholarsArchive. It has been accepted for inclusion in Faculty Publications by an authorized administrator of BYU ScholarsArchive. For more information, please contact ellen_amatangelo@byu.edu. 


\section{Authors}

Alan J. Hawkins, Scott M. Stanley, Philip A. Cowan, Frank D. Fincham, Steven R. H. Beach, Carolyn Pape Cowan, Galena Kline Rhoades, Howard J. Markman, and Andrew P. Daire 


\section{Comment}

\section{Contents}

Hawkins et al. on Johnson 110

Johnson replies 111

DOI: $10.1037 / \mathrm{a} 0031792$

\section{A More Optimistic Perspective on Government-Supported Marriage and Relationship Education Programs for Lower Income Couples}

\author{
Alan J. Hawkins \\ Brigham Young University \\ Scott M. Stanley \\ University of Denver \\ Philip A. Cowan \\ University of California, Berkeley \\ Frank D. Fincham \\ Florida State University \\ Steven R. H. Beach \\ University of Georgia \\ Carolyn Pape Cowan \\ University of California, Berkeley \\ Galena Kline Rhoades and \\ Howard J. Markman \\ University of Denver \\ Andrew P. Daire \\ University of Central Florida
}

In the past decade, the federal government, some states, and numerous communities have initiated programs to help couples form and sustain healthy marriages and relationships in order to increase family stability for children. Thus, we value the attention given to this emerging policy area by the American Psychologist in a recent article (Johnson, May-June 2012). However, it is important to challenge some of Johnson's points about the effectiveness and reach of interventions to lower income couples and couples of color and his sug- gested prioritization of basic over applied research.

Johnson (2012) questioned whether marriage and relationship education (MRE) initiatives targeted to lower income individuals and/or minorities can be effective in anything like their current forms because much of the research on MRE has been based on middle-class, Caucasian couples. Johnson pointed to two large, rigorous evaluation studies with lower income, racially and ethnically diverse couples: Building Strong Families (BSF; Wood, McConnell, Moore, Clarkwest, \& Hsueh, 2010) and Supporting Healthy Marriages (SHM; Hsueh et al., 2012). As Johnson accurately noted, the statistically significant effects in one study (SHM) were small, and in the other (BSF), significant results were confined mostly to one large site that was successful in retaining participants for substantial doses of the intervention (Oklahoma City). The significant effects in these two trials are indeed modest; improvements are needed. But we believe these and other studies provide some basis for optimism in this area of preventive education, especially in light of the fact that many more costly government-supported programs, including teen pregnancy prevention, drug abuse interventions, and employment services, have struggled to document significant impacts (see the 2011 GAO report on jobs programs, where the rarely documented effects tend "to be small, inconclusive, or restricted to shortterm impacts" [United States Government Accountability Office, 2011, p. 11]).

Given Johnson's (2012) primary arguments about couples of color, it is noteworthy that he gave brief and no attention, respectively, to findings from the largescale trials he mentioned that minority couples were more likely to show significant benefits (African American couples in BSF [Wood et al., 2010] and Hispanic couples in SHM [Hsueh et al., 2012]). There are other studies that Johnson did not mention, and that he may not or could not have known about in writing his critique, that support our basis for more optimism in MRE efforts. In a recent meta-analysis of 50 programs supported by federal funds (reaching nearly 50,000 lower income participants) and evaluated by program pro- viders with pre-post field data (no control group), statistically significant, generally moderate effect sizes were found for each target population and outcome assessed, and these effects were generally stronger for less educated participants (Hawkins \& Fellows, 2011). In a rigorous randomized controlled trial study of nearly 500 young and married Army couples in a stressful context (e.g., deployments), those receiving one of the most tested MRE programs had a significantly lower likelihood of divorce one year following training (Stanley, Allen, Markman, Rhoades, \& Prentice, 2010). These participants were lower income couples (although they cannot be compared to low-income civilian couples with less access to various resources). Moreover, the two-year outcomes in this study (being prepared for publication) showed the significant divorce reduction effect was maintained and that minority couples received the largest divorce reduction effect. Other studies also are demonstrating significant impacts from MRE efforts with lower income and/or minority couples (Bradley, Friend, \& Gottman, 2011). In addition, one such study even showed positive effects on parenting and children's problem behaviors (Cowan, Cowan, Pruett, Pruett, \& Wong, 2009). Another study suggests that impacts from these government-supported programs may be beginning to register at the demographic level (Hawkins, Amato, \& Kinghorn, in press).

Johnson (2012) also suggested that lackluster impacts from the recent efforts were based on inadequate basic science about the risks and developmental course of relationships for low-income and minority couples. We agree that there needs to be more research on basic risk and protective factors, and we think the emphasis he places on the role of stress in the lives of low-income couples is particularly promising. In fact, such research was influential in the adaptation of interventions in the largescale intervention studies cited earlier. Further, there was more reliance on empiricism in many efforts than the subtitle of Johnson's article would suggest. We also are not convinced by his assertion that there is, at present, one "best supported model of marriage" (Johnson, 2012, p. 
301) that may or may not apply to disadvantaged couples. While broadening the knowledge of risk models has the potential to contribute to progress, as suggested by Johnson, so does ongoing feedback between tests of theory and application.

Johnson (2012) also questioned whether disadvantaged couples can be reached with these types of efforts. Reach is, indeed, crucial. Again, we take note of the evidence from recent federally supported efforts. For example, Bradbury and Lavner (2012) suggested that the SHM study provided "real cause for optimism" regarding reach: $75 \%$ of the 6,300 couples were below $200 \%$ of the poverty line, only $30 \%$ were White (non-Hispanic), and $80 \%$ completed an average of 20 hours of the intervention (pp. 118-119). This evidence of reach and sustained interest among lower income couples has been encouraging if not remarkable, and work on effective outreach to disadvantaged and minority individuals is progressing.

With emerging findings and practical knowledge gained in lower income communities from all across the United States over the past decade, we see evidence to support optimism for the potential utility of MRE programs to help disadvantaged and minority couples. Accordingly, continued support for these efforts is justified. We anticipate that the potential of these firstgeneration programs will only increase as the research Johnson (2012) called for advances our understanding of low-income and minority couple relationships, as more programs are rigorously evaluated, and as we learn and disseminate best practices from programs now in the field. Even small program effects are likely to produce significant taxpayer savings given the public (and private) costs associated with family instability and relationship dysfunction.

\section{REFERENCES}

Bradbury, T. N., \& Lavner, J. A. (2012). How can we improve preventive and educational interventions for intimate relationships? $\mathrm{Be}$ havior Therapy, 43, 113-122. doi:10.1016/j beth.2011.02.008

Bradley, R. P. C., Friend, D. J., \& Gottman, J. M. (2011). Supporting healthy relationships in low-income, violent couples: Reducing conflict and strengthening relationship skills and satisfaction. Journal of Couple \& Relationship Therapy, 10, 97-116. doi:10.1080/ 15332691.2011.562808

Cowan, P. A., Cowan, C. P., Pruett, M. K., Pruett, K., \& Wong, J. J. (2009). Promoting fathers' engagement with children: Preventative interventions for low-income families. Journal of Marriage and Family, 71, 663679. doi:10.1111/j.1741-3737.2009.00625.x

Hawkins, A. J., Amato, P. R., \& Kinghorn, A. (in press). Are government-supported healthy marriage initiatives affecting family demographics? A state-level analysis. Family Relations.

Hawkins, A. J., \& Fellows, K. J. (2011). Findings from the field: A meta-analytic study of the effectiveness of healthy marriage and relationship education programs. Washington, DC: National Healthy Marriage Resource Center. Retrieved from http://www.healthy marriageinfo.org/resource-detail/index.aspx? rid $=3928$

Hsueh, J., Alderson, D. P., Lundquist, E., Michalopoulos, C., Gubits, D., Fein, D., \& Knox, V. (2012). The Supporting Healthy Marriage evaluation: Early impacts on low-income families (OPRE Report 2012-11). Washington, DC: Office of Planning, Research, and Evaluation, Administration for Children and Families, U.S. Department of Health and Human Services.

Johnson, M. D. (2012). Healthy marriage initiatives: On the need for empiricism in policy implementation. American Psychologist, 67, 296-308. doi:10.1037/a0027743

Stanley, S. M., Allen, E. S., Markman, H. J., Rhoades, G. K., \& Prentice, D. (2010). Decreasing divorce in Army couples: Results from a randomized clinical trial using PREP for Strong Bonds. Journal of Couple \& Relationship Therapy, 9, 149-160. doi:10.1080/ 15332691003694901

United States Government Accountability Office. (2011). Multiple employment and training programs: Providing information on colocating services and consolidating administrative structures could promote efficiencies (Report No. GAO-11-92). Washington, DC: Author.

Wood, R. G., McConnell, S., Moore, Q., Clarkwest, A., \& Hsueh, J. (2010, May). The Building Strong Families project: Strengthening unmarried parents' relationships: The early impacts of Building Strong Families. Princeton, NJ: Mathematica Policy Research.

The contributions of Scott M. Stanley, Howard J. Markman, and Galena K. Rhoades to this article were supported in part by awards from the Eunice Kennedy Shriver National Institute of Child Health and Human Development (R01HD048780 and R0HD053314). The content is solely the responsibility of the authors and does not necessarily represent the official views of the Eunice Kennedy Shriver National Institute of Child Health and Human Development or the National Institutes of Health.

Full disclosure of interests: Scott M. Stanley and Howard J. Markman own a business (PREP Inc.) that develops, refines, disseminates, and sells relationship education curricula (such as PREP, Within Our/My Reach). Galena K. Rhoades has been involved in developing relationship education curricula for PREP Inc. and receives royalties on the sales of some of its relationship education materials.

Correspondence concerning this comment should be addressed to Alan J. Hawkins, School of Family Life, 2050 Joseph F. Smith Building, Brigham Young University, Provo, UT 846026723. E-mail: hawkinsa@byu.edu

\section{DOI: $10.1037 / \mathrm{a} 0031793$ \\ Optimistic or Quixotic? More Data on Marriage and Relationship Education Programs for Lower Income Couples}

\author{
Matthew D. Johnson \\ Binghamton University
}

I am gratified and encouraged that such an esteemed group of relationship scientists as Hawkins et al. (2013, this issue) want to continue the discussion of governmentsupported marriage and relationship education (MRE) programs for lower income couples by responding to my article (Johnson, May-June 2012). In their comment, they argued that there are data that support the efficacy of MRE programs for disadvantaged couples and that the benefits of these programs outweigh the costs. My response to both of these points follows.

\section{Data Do Not Support the Efficacy of MRE Programs for Disadvantaged Couples}

Hawkins et al. (2013) noted that MRE programs for poor couples and families of color are more effective than I suggested. They pointed to a few individual variables across multiple studies in which there were small, but significant, effects. The authors found cause for optimism in these inconsistent and small effects across many studies. The data they cited have three problems that strongly suggest a need for greater skepticism rather than optimism.

First, the data they cited were selected in a way that suggests that their conclusions may be resting on Type I error because they failed to mention how many of the outcome variables within each study were null. For example, they wrote that the 15-month outcome data for the Building Strong Families (BSF; Wood, McConnell, Moore, Clarkwest, \& Hsueh, 2010) study had "significant results [that] were confined mostly to one large site that was successful in retaining participants for substantial doses of the intervention (Oklahoma City)" (Hawkins et al., 2013, p. 110); however, there were actually two sites that showed small effects-one had negative effects (Baltimore) and one had positive effects. In another example, the authors cited a study (Bradley, Friend, \& Gottman, 2011) as "demonstrating significant impacts from MRE efforts" (Hawkins et al., 2013, p. 110 ), but they failed to mention that only women's relationship satisfaction im- 